\title{
INTRODUCTORY PAPER \\ SCIENTIFIC RESULTS ON THE TURIN SHROUD COMING FROM A PADUAN UNIVERSITY RESEARCH PROJECT
}

\author{
Giulio Fanti \\ Department of Industrial Engineering, University of Padova, Italy \\ giulio.fanti@unipd.it, http://www.dii.unipd.it/-giulio.fanti
}

\begin{abstract}
Turin Shroud (TS) is a linen cloth $4.4 \mathrm{~m}$ long and $1.1 \mathrm{~m}$ wide which shows two, front and back images of a man scourged, crowned with thorns and crucified, who died on a cross and was stabbed in the side with a lance after his death. The Catholic Christian tradition identifies this Man as Jesus Christ resurrected after dead, but not all are unanimous in this identification, partly because science has not been able to give definitive answers. To try to improve a bit the inconclusive answers to which the Science is arrived, a Research Project entitled: "Multidisciplinary analysis applied to the Turin Shroud: study of the body image, of possible ambient pollution and of micro-particles capable to characterize the linen fabric." has been assigned by the University of Padua (Italy) to the Author, who performed various studies on this theme in collaboration with other experts, also of other Italian Universities. In reference to the body image, that is not explainable by Science nor reproducible up to now, experimental tests based on Corona Discharge, produced by intense electric fields, have shown that it is possible to reproduce many of these very peculiar image features. Regarding the TS dating, after the demonstration that the 1988 radiocarbon result is not statistically reliable, probably because of environmental pollution, alternative dating methods based on chemical and mechanical tests showed that its age is compatible with the period in which Jesus Christ lived in Palestine.
\end{abstract}

\section{Introduction}

The Turin Shroud [1,2] (TS) is a handmade 3-1 twill linen cloth, $4.4 \mathrm{~m}$ long and $1.1 \mathrm{~m}$ wide, on which the complete front and back images of a human body are indelibly impressed (Figure 1). The word "shroud" corresponds to the Italian "Sindone" deriving from the Ancient Greek " $\sigma \iota v \delta \omega ́ v=$ sindòn", meaning the burial cloth in which a corpse is wrapped. The term "sindon" seems to derive from "sindia", a cloth made in India.

According to the Catholic Christian tradition, the TS is the burial cloth in which Jesus Christ was wrapped before being placed in a tomb in Palestine about 2000 years ago; for this reason, it is the most important Relic of Catholic Christianity. Even if the Science has not demonstrated the contrary, the Catholic Christian Church does not impose any veneration of it. 
There are some indications that the TS was in Palestine in the first century A.D.: for example, "De Viris illustribus" (a manuscript by Jerome of the II century A.D.) contains a passage of the Hebrews' Gospel in which it is reported that the Shroud was given to the servant of a priest. According to many scholars [3] the TS was then taken in Edessa (current Salinurfa in Turkey).

The face of Christ on Byzantine coins in the VII century A.D. is very similar to that on the TS: the engraver who coined the first face of Jesus Christ on the gold solidi of Justinian II in 692 A.D. had only seven chances over one billion of billions to reach that the results without having looked at the TS [2]. In 1203, a crusader noted that a church in Constantinople was accustomed to exhibiting every Friday a cloth in which it was stated that Christ had been buried, with the figure of his body impressed on it.

The "Shroud of Christ" appeared in Europe in 1353 at Lirey [3] in France, during a dispute for its ownership between the owner Geoffry de Charny and the canons of Lirey with the bishop of Troyes, Pierre d'Arcis; the king of France, Charles VI, and the anti-pope, Clemens VII, were also involved in this dispute.

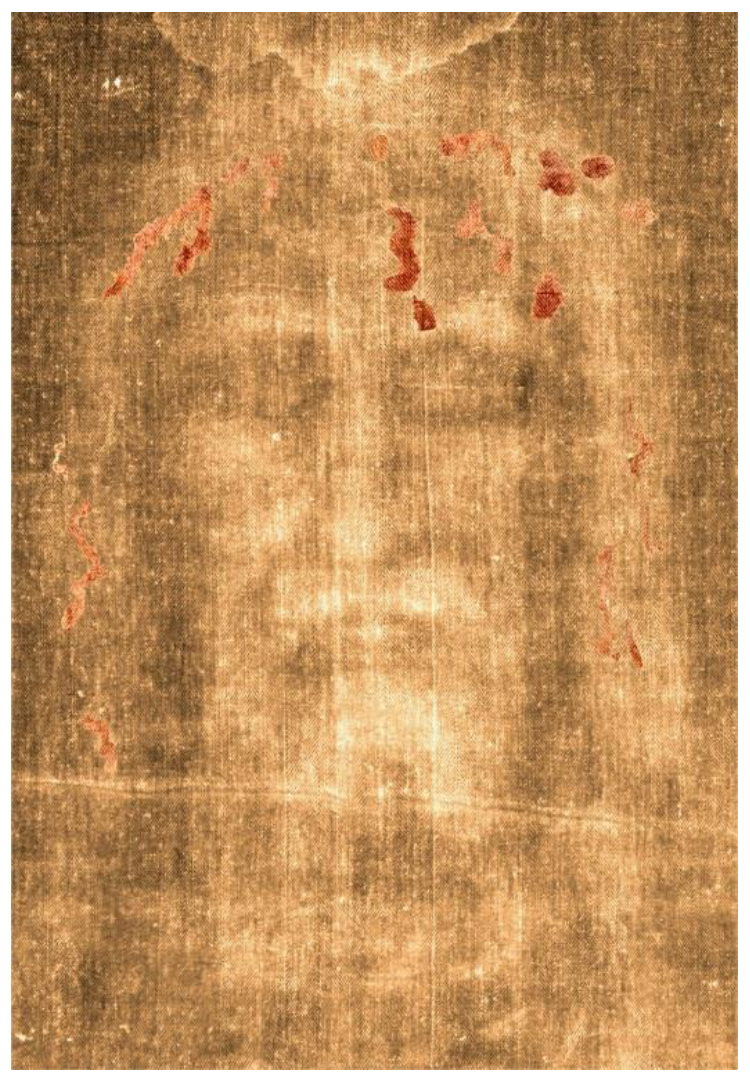

Figure 1. Face of TS. To the negative body image, the positive blood stains have been superimposed.

A fire damaged the TS in 1532, while it was conserved in a reliquary at Chambery in France. The Chambéry nuns later restored it by sewing some patches of cloth that have been removed in 2002 . The TS, after being displaced at Nizza in France and in other cities, like Vercelli, was taken in Turin in 1578.

Until the XIX century, scientific interest in the TS was limited, because of the scarcity of direct analyses and the lack of photographs. Interest greatly developed after 1898, when S. Pia photographed it and sent copies to the scientific world for independent studies, discovering that the body image is like a photographic negative. 
In 1988, the TS was radiocarbon-dated to 1260-1390 A.D. [4], but the results are questionable [5,6]. As the process that formed the body image is still unknown, the dating method cannot be rigorously applied because the environment in which the object under analysis was conserved must be known from a contamination point of view. The imaging mechanism may in fact have varied the percentage of carbon isotopes of the TS, thus producing a non-negligible systematic effect. In addition, the 1988 sample resulted not representative of the whole TS, because its chemical characteristics differ from the main part [7].

Many hypotheses have been formulated [8] to explain the double body image that up to now is impossible to be reproduced. The most reliable of them makes reference to a burst of energy coming from the inner of the enveloped human body and, among the various energy source proposed, that referring to a Corona Discharge [9] (connected with a very intense electric field) is able to explain a greater number of the peculiar features detected on the TS.

\section{Purposes of the Research Project}

In order to try to find answers to the major problems related to the TS, or at least to improve the knowledge about them, some Paduan researchers grouped in the University Research Project (URP) entitled: "Multidisciplinary analysis applied to the Turin Shroud: study of the body image, of possible ambient pollution and of micro-particles capable to characterize the linen fabric." In particular, the following questions have been posed by the Project:

-1 . How did the body image formed?

-2. How much old is the linen fabric?

-3. Can we get some additional information from the TS particles?

-4. Can we get some additional information about the Man enveloped into the TS?

This section concerns an introduction to these arguments.

\subsection{How did the body image formed?}

The front and back images of the TS show an adult male, nude, well-proportioned and muscular, with beard, moustache and long hair, and are compatible with a man $175 \pm 2 \mathrm{~cm}$ tall enveloped in a sheet [10] After stretching the sheet during the 2002 intervention, the Man resulted a bit taller, about $177 \pm$ $2 \mathrm{~cm}$; this fact implies that probably in the past, before other possible lengthening perhaps produced during exhibitions, the body image originally corresponded to a man about $170 \mathrm{~cm}$ tall. The image has many peculiar physical and chemical features, which cannot be reproduced all together [11]. Even if some scholars [12] have attempted to reproduce the TS, their results are not able to replicate many particular features [13], especially at microscopic level.

The linen sheet enveloped the corpse of a man who died on a cross $[8,14,15]$. The front and back images visible on it are compatible with a man who was scourged, crowned with thorns, crucified and who was stabbed in the right side with a lance after his death.

The most important and reliable scientific analysis on the TS was performed in 1978 by the STURP (Shroud of TUrin Research Project) [14,16], a group of 52 American scientists who worked non-stop on the cloth for 120 hours. They concluded that the body image on the TS cannot be scientifically explained, and their only attempt at explanation consisted of stating that the image formed as if it were caused by exposure to a short-lived but intense source of energy coming from the body wrapped in the TS itself.

The cause of the yellowing of the body image in visible light is due to chemical alteration of the polysaccharides contained in the linen fibers, consisting of chemical structures formed by dehydration, oxidation and conjugation products in the linen itself. This chemistry is similar to the characteristics of aging linen [16].

The front and back images are superficial $[8,11]$ not only at thread level, but also at fiber level because only the Primary Cell Wall is colored, while the inner cellulose is not. There are also uncolored fibers 
posed side by side with colored ones. The presence of an image on the back of the TS was recently detected [17,18].

We know little if any about the process that generated the body image on the linen fabric of the TS. Many scholars have proposed several different hypotheses to account for the formation of the image $[2,8]$, but their results appear inadequate. The most important hypotheses are the following.

- Gas diffusion. R. Rogers [19] made reference to the Maillard reaction as the cause of the body image formation presuming the interaction of amines (generated by the human body during decomposition) with a polysaccharide layer (the linen fabric was supposed to be formed by starch all around the fibers) that produced the color of the external fibers of the TS.

- Contact hypothesis. J. Volkringer [20], studying imprints in old herbaria, caused by the pressure of leaves, hypothesized that the TS image was produced by direct body/sheet contact, as a consequence of a similar natural chemical reaction.

- Artistic copies. Many copies of the TS have been made by artists since the Middle Age, and many of them were painted in contact with the original TS in order to make the copies second-order relics; on these copies there is an explicit declaration that the artwork was copied from the original. At the end of the 20th century instead various scholars [12,21-23] hypothesized the original TS as the result of a Middle Age artist, but without furnishing a reliable explanation of how this artist was able to obtain his result.

- Hypothesis of radiation. The majority of scientists have formulated different hypotheses of body image formation based on "energy radiation" intended in a wide sense, as a process acting at a distance. In fact there are some areas on the TS image, like those between the cheeks and nose, where a body/cloth contact cannot be supposed. In addition this "energy radiation" was generated by the enveloped human body because the most intense fabric coloration appears on the side where the cloth touched the cadaver (the bloodstains features also confirm this).

It is interesting here to observe here that the "energy" must have been consisted as a short-lived burst to explain the image of Fig. 1. In fact the bloodstains on the hair are coherent with a wrapping of the TS around the face that produced a cylindrical distortion, while the body image (that formed later) is coherent with a flatter position of the fabric enveloping the human body (with a radiation almost vertical and no evident image distortion), probably due to a pressure increment of the air under the sheet, connected with the burst of "energy".

This result is the consequence of the fact that some bloodstains are very peculiar and can be explained only with the hypothesis of a burst of "energy". For example the bloodstain on the right hair at check level, is not typical of hair wetted of blood (that would have produced a different stain, with much less detailed edges), but are instead typical of a direct skin-fabric contact. If therefore the TS must have touched a wound near the ear, and now we see this wound superimposed to the image of hair, we have to suppose that the TS had two different wrapping configurations: a first one tight, during the bloodstain formation coherent with a distortion of cylindrical type, and a second one with the TS flatter due to the burst of energy.

Neither this, nor URP are the suitable places where to discuss how this "energy" was produced, especially if we think that the Man in question was dead, but it is here of interest to try to find a scientific explanation of what it has been detected from the direct studies on the body image features.

J. B. Rinaudo [24], hypothesized a proton radiation that produced the body image, coupled with a neutron radiation (coming from the disintegration of deuterium atoms present in the human body), that caused a rejuvenation of the carbon-14 age of the fabric; J. Jackson [25] assumed that a burst of energy, prevalently of soft UV type, formed the TS image; a group of scientists led by G. Baldacchini [26] proposed excimer lasers to partially verify the J. Jackson's hypothesis.

The author and other researchers are convinced that the most probable hypothesis, also supported by experimental results, is based on Corona Discharge [9,27]. Nevertheless, no complete results can be obtained because of the difficult and, in some cases, dangerous environmental conditions (e.g. for the 
presence of radon) required for these experiments. For the time being, Corona Discharge may be caused by various more or less identified sources such as (ball) lightning, earthquakes and radioactive environments (radon), but perhaps the truth is beyond the Science. Imaging of the TS by a Corona Discharge may even be a by-product of the Resurrection [9], and this may be why the image cannot be technically reproduced or scientifically explained in a complete form. By means of the present URP some progress about these hypotheses has nevertheless been obtained [28].

\subsection{How much old is the linen fabric?}

In 1988 the TS has been radiocarbon dated [4] to 1260-1390 A.D. at 95\% confidence level with evident statistical errors [6] that made this result doubtful. Perhaps the most evident demonstration that these results are not coherent with the assigned uncertainty of \pm 65 years at $95 \%$ confidence level is the following: the twelve published results are in a much wider range of 204 years (1155-1359 A.D.).

According to some scholars, it must also not be excluded the possibility that the sample of the TS used for the 1988 test was not representative of the original [7,15] because picked up from a Medieval mending.

Other studies evidenced problems with this result too [29,30], but the most important problem related to this dating is a non-negligible spatial trend [2], that leads to think to an important contamination perhaps due to environmental factors, not excluded that correlated to the energy perhaps produced during the body image formation. In fact we must remember that the body image has not yet been explained, and therefore the environment in which the TS was exposed in the past is not known.

In this view the development of alternative dating methods of the TS appear necessary; a numismatic dating of the TS based on the concordance of the TS face with that of Christ minted in the Byzantine coins $[2,31]$ has already cast doubts about the 1988 results, but the URP allowed the development of new chemical and mechanical dating methods.

\subsection{Can we get some additional information from the TS particles?}

In various occasions, but principally in 1978 during STURP campaign [14,16], particles have been picked up from the TS either using sticky tapes put in contact with the Relic or vacuuming the side of the TS put in contacts with the reinforcing Holland Cloth by means of a special aspirator connected with proper filters [32]. Some of those particles have been furnished to the coordinator of the URP who used them for various kinds of analyses.

In particular clumps of these particles have been used to DNA tests in order to determine either which kind of plants contaminated the linen fabric or which kind of persons polluted the Relic by touching or kissing it.

Clumps of particles, having sizes of the order of 10 micrometers, coming from the vacuumed dusts have been also mounted on proper stubs to perform SEM, ESEM and EDX analysis to verify the presence of pollen grains, blood, spices, fungi and bacteria and hopefully to classify them in order to confirm previous analyses $[33,34,35,36,37,38,39]$ performed on different samples coming from the TS.

\subsection{Can we get some additional information about the Man enveloped into the TS?}

It is scientifically demonstrated that the TS Man was enveloped in the TS as a corpse [40,41], but up to now it is not yet clear which was the real cause of his death. Many researchers $[42,43,44]$ proposed different causes of death like hemothorax, hemopericardium, induced coagulopathy and asphyxia basing their conclusion on almost subjective deductions but up to now no common agreement has been found.

The URP was also addressed to perform a detailed study of all the characteristics of the corpse shown on the TS in order to better evidence the real cause of death and other related aspects. For example the 
following question was posed: did the Man carried the cross or the patibulum? To reach this goal, a group of physicians leaded by M. Bevilacqua formed to verify what is really visible on the TS body image, also reinforcing their results by means of experimental tests, performed on parts of cadavers furnished by the R. De Caro's team of the Institute of Anatomy of the University of Padua.

\section{Results of the Research Project}

The present issue groups together the principal results obtained by the URP that have been exposed at WOPSAS (WOrkshop of Paduan Scientific Analysis on the Shroud). In reference to the four questions posed in Section 2, here are synthetically reported the following results.

\subsection{The body image formation}

It is well known that the body image formation process is not explainable in the whole and it was probably a burst of "energy" (intended in a wide sense as a process acting at a distance) that formed the image we see on the TS. In order to better understand the nature of this body image, some studies have been performed to quantify its color range as a function of different anatomical parts and to show the color differences among the other stains like blood and water.

The C. Privitera [45] of CRIS (Comitato di Ricerca Ingegneristica sulla Sindone - Committee for Engineering Research on the Shroud, a new group composed of engineers who performed their degree thesis and/or made some research on the TS at Padua University) made a colorimetric analysis of the TS basing on previously acquired data by beans of certified instruments; he arrived to build a quantitative photography of the TS useful to measure the tristimulus color levels in RGS and XYZCIE color spaces. The innovation consists in the possibility of colorimetrically measuring the TS through common tools.

A group of engineers leaded by G. Bedon [46] of CRIS also performed a chromatic analysis of the bloodstains of the TS to characterize the various stains present on the TS.

The most probable source of energy is of electric type and connected to the Corona Discharge [9,27]. Some experiments have been performed to reproduce the TS body image and some interesting results have been recently published [28]. F. Lattarulo presents in this issue, an electrostatic hypothesis that could have produced the image.

\subsection{Age of the linen fabric}

Once ascertained that the 1988-radiocarbon result is not reliable, at least from a statistical point of view $[6,29,330]$, alternative dating methods are necessary to give information on the age of the TS fabric. Two chemical methods based on FT-IR and Raman spectrometry have been proposed to date the TS [51] and the results of these methods are here presented by P. Baraldi and A. Tinti in this issue. The author with P. Malfi [48] proposed a multi-parametric mechanical method, using a special machine built for the purpose and some preliminary results have been published in Ref. [49]. These and other chemical results based on Raman and FT-IR spectrometry [47] are synthetized in this issue also evidencing some dependences among the mechanical parameters considered.

With R. Basso, a Monte Carlo method has been applied in the present issue to the results deriving from the mechanical dating in order to better evaluate the uncertainty propagation to the results reported in Ref. [49]; a substantial confirmation of the previous results is there showed.

These alternative dating methods show that the age of the TS is compatible with the first Century A.D., period in which Jesus Christ lived in Palestine. 


\subsection{Information from the TS particles}

The URP addressed the study on the particles coming from the TS along two avenues. The first one performed a microscopic recognition of the particles in question by using various kinds of tools like optical microscope, SEM (Scanning Electron Microscope) and ESEM (Environmental Scanning Electron Microscope) with EDX (Energy Dispersive X-ray) [50].

In this way previous pollen analyses [33,34,39] recently put in discussion [40] have been instead confirmed; the structure of the linen of TS fibers have been evidenced; particles of various kinds, molds and mites have been classified thus helping in the understanding which environmental conditions was subjected the Relic in the past centuries. I. Calliari with C. Canovaro presents these results in the present issue.

The second one was addressed to the analysis of the DNA particles contained in the TS dusts [51]. In particular the analysis of genomic DNA extracted from the dusts was used to study chloroplast DNA and to define several plant taxa. Many of them resulted native to the Mediterranean area as well as species with a primary center of origin in Asia, the Middle East or the Americas.

Human mitochondrial DNA was also extracted from the TS dusts, with detection of sequences from multiple subjects, which clustered into a number of Western Eurasian haplogroups, including some known to be typical of Western Europe (H1 and H3), the Near East (H13 and H33), the Arabian Peninsula (R0a) and the Indian sub-continent (M39, M56 and R8).

These findings are therefore in agreement with the hypothesis of contact with individuals of different ethnic origins, compatible with the historic path followed by the Relic during its journey from the Near East. This study also evidenced the possibility of an Indian manufacture of the linen cloth and these findings are reported in a paper of this issue written by G. Barcaccia et al.

\subsection{Information about the Man enveloped into the TS}

The analysis of the TS image from a medical point of view evidenced [52] that the injuries visible on the TS body image are in agreement with the Man suffering a violent blunt trauma to the neck, chest and shoulder from behind, causing lesions of the entire brachial plexus during the cross transportation. The blunt chest trauma, which resulted in the body falling forwards, was the direct cause of a lung contusion and haemothorax (confirmed by the post-mortem leakage of clots and serum from the chest) and was a likely cause of cardiac contusion.

The wrists were probably nailed in the Destot space with ulnar artery cutting and partial tear of the ulnar nerve that caused thumb retraction. The right foot was probably dislocated to the ankle. The likely cause of immediate death was a myocardial infarction with hearth rupture, haemopericardium and tamponade of a subject with cardiac contusion [53]. M. Bevilacqua et al. described in details the status of the TS Man in the present issue.

\section{Conclusion}

This paper presents the main results of the scientific research performed on the Turin Shroud by the URP. The following questions have been posed by the Project:

-1. How did the body image formed?

-2 . How much old is the linen fabric?

-3. Can we get some additional information from the TS particles?

-4. Can we get some additional information about the Man enveloped into the TS?

The answers are synthetically reported in this collection of papers. In reference to Point 1, ascertained that the body image formation process is not explainable in the whole, it is discussed why this process was probably due to a source of "energy"; the most probable one is of electric type and connected to the Corona Discharge [9,27,28].

In reference to Point 2, ascertained that the 1988-radiocarbon result is not reliable [5,6,7], at least from a statistical point of view, alternative dating methods of chemical and mechanical types have 
been developed $[2,47,48,49]$ showing that the age of the TS is compatible with the first Century A.D., period in which Jesus Christ lived in Palestine.

In reference to Point 3, two ways have been followed. The first one performed a microscopic recognition of the dust particles both confirming pollen analyses [33,34,39] recently put in discussion [40] and classifying other particles of various kinds. The second one was addressed to the analysis of the DNA particles [51] through the extraction of both chloroplast DNA to define several plant taxa and human mitochondrial DNA to detect the different haplogroups of persons who entered in contact with the Relic.

In reference to Point 4, the Man suffered a violent blunt trauma to the neck, chest and shoulder from behind, causing lesions of the entire brachial plexus. The trauma was produced by the TS Man falling forwards, during the cross transportation. The likely cause of immediate death was a myocardial infarction with rupture, haemopericardium and heart tamponade $[52,53]$.

All the evidence is in favor of the hypothesis that the TS Man is Jesus of Nazareth.

\section{Acknowledgements}

This work has been done with the support of the University Research Project - Padova, Italy 2009 \#CPDA099244 entitled "Multidisciplinary Analysis Applied to the Shroud of Turin: a study of body image, of possible environmental pollution and of microparticles characterizing the linen fabric." The Author thanks the Rector of Padua University, prof. Giuseppe Zaccaria, both for having allowed the organization the WOPSAS meeting and for having promoted, also with a grant (Decr. Rep. n.2463/2015, Prot. 214307), the publications of this collection of papers.

\section{References}

1. G. Fanti, R. Basso, "The Turin Shroud, Optical Research in the Past Present and Future", Publisher Nova Science Pub Inc., USA, March 2008.

2. G. Fanti, P. Malfi, "The Shroud of Turin - First century After Christ!", Pan Stanford Publishing Pte. Ltd., Singapore, 2015.

3. I. Wilson, V. Miller, "The Mysterious Shroud“, Doubleday Image Book, USA, 1986.

4. P.E. Damon, Donahue D.J., Gore B.H., Hatheway A.L., Jull A.J.T., Linick T.W., Sercel P.J., Toolin L.J., Bronk C.R., Hall E.T., Hedges R.E.M., Housley R., Law I.A., Perry C., Bonani G., Trumbore S., Wölfli W., Ambers J.C., Bowman S.G.E., Leese M.N., Tite M.S., "Radiocarbon dating of the Shroud of Turin", Nature, Vol. 337, February 16, 1989, pp. 611-615.

5. B. J. Walsh, "The 1988 Shroud of Turin Radiocarbon Tests Reconsidered", Shroud of Turin Center, Richmond, Virginia USA, 1999, pp. 326-342.

6. M. Riani, A. C. Atkinson, G. Fanti, F. Crosilla: "Regression analysis with partially labelled regressors: carbon dating of the Shroud of Turin" Journal of Statistical Computing. Stat. Comput. (2012).

7. R. Rogers, "Studies on the radiocarbon sample from the Shroud of Turin", Thermochemical Acta, Vol. 425, Issues 1-2, 20, Jan. 2005, pp. 189-194.

8 G. Fanti, "Hypotheses regarding the formation of the body image on the Turin Shroud. A critical compendium", J. of Imaging Sci. Technol., Vol. 55, No.6, p. 060507 (2011).

9. G. Fanti, "Can Corona Discharge explain the body image formation of the Turin Shroud?", J. of Imaging Science and Technology, Vol. 54, No. 2, pp. 020508-1/10 (2010).

10. G. Fanti, R. Basso, G. Bianchini, "Turin Shroud: Compatibility Between a Digitized Body Image and a Computerized Anthropomorphous Manikin", J. of Imaging Sci. Technol., 54 No.5, p. 050503-1/8, (2010).

11. G. Fanti, J.A. Botella, P. Di Lazzaro, T. Heimburger, R. Schneider, N. Svensson,” Microscopic and Macroscopic Characteristics of the Shroud of Turin Image Superficiality", J. of Imaging Sci. Technol., 54 No. 4, p. 040201-1/8, (2010). 
12. L. Garlaschelli, Life-size Reproduction of the Shroud of Turin and its Image, J. of Imaging Science and Technology 54(4): 040301-1/040301-14 (2010).

13. G. Fanti, T. Heimburger, "Letter to the Editor: Comments on - Life-Size Reproduction of the Shroud of Turin and Its Image" by L. Garlaschelli- "J. Imaging Sci. Technol. Vol. 55, 020102 (Feb. 25, 2011).

14. E.J. Jumper, Adler A.D., Jackson J.P., Pellicori S.F., Heller J.H., Druzik J.R., “A comprehensive examination of the various stains and images on the Shroud of Turin", Archaeological Chemistry III, ACS Advances in Chemistry n ${ }^{\circ}$ 205, J.B. Lambert, Editor, Chapter 22, American Chemical Society, Washington D.C., 1984, pp. 447-476.

15. A. D. Adler, "Updating recent studies on the Shroud of Turin", American Chemical Society, Symposium Series No. 625, Archaeological Chemistry 625, 223-228, (1996).

16. L. A. Schwalbe, R.N. Rogers, "Physics and chemistry of the Shroud of Turin, a summary of the 1978 investigation", Analytical Chemical Acta, Vol. 135, pp. 3-49, (1982).).

17. Fanti, R. Maggiolo, "The double superficiality of the frontal image of the Turin Shroud", J. of Optics A: Pure and Applied Optics, volume 6, issue 6, 2004, pages 491- 503.

18. G. Fanti, R. Maggiolo, "About the second image of face detected on the Turin Shroud", Int. Conference on the "Shroud of Turin: The Controversial Intersection of Faith and Science", St. Louis, Missouri (2014), www.shroud.com/pdfs/stlfantil.pdf

19. R. Rogers, A Chemist's perspective on the Shroud of Turin, Lulu.com (2008).

20. J. Volckringer, The Holy Shroud: science confronts the imprints, The Runciman Press, Manly, Australia (1991) p.10.

21. E. A. Craig, R. R. Bresee, Image Formation and the Shroud of Turin, Journal of Imaging Science and Technology, 34(1), pp. 59-67, (1994).

22. V. Pesce Delfino, E l'uomo creò la Sindone, Ed. Dedalo, Bari (2000) p.49.

23. J. Nickell, Inquest on the shroud of Turin, Prometheus Books, Buffalo New York (1998) p.101.

24. B. Rinaudo, Image formation on the Shroud of Turin explained by a protonic model affecting radiocarbon dating, III Congr. Int. di Studi sulla Sindone, Turin, Italy (1998) Proc. on CD pp. 474483.

25. J. P. Jackson, "Does the Shroud of Turin show us the Resurrection?" Biblia y Fé, (1998).

26. G. Baldacchini, P. Di Lazzaro, D. Murra, G. Fanti: "Coloring Linens by Excimer Lasers to Explain the Body Image of the Turin Shroud" Applied Optics Vol. 47, No. 9, 20, pp. 1278-1285 (2008).

27. G. Fanti, F. Lattarulo, O. Scheuermann: "Body Image Formation Hypotheses Based on Corona Discharge", Third Dallas Int. Conf. on the Shroud of Turir, Texas (2005), www.dim.unipd.it/fanti/corona.pdf

28. G. Fanti, F. Lattarulo, G. Pesavento, "Experimental Results Using Corona Discharge to Attempt to Reproduce the Turin Shroud Image", ATSI 2014, WOPSAS, Bari, Italy (2014), http://www.shsconferences.org/articles/shsconf/pdf/2015/02/shsconf_atsi2014_00003.pdf

29. R. Van Haelst "Radiocarbon dating the Shroud of Turin - A critical statistical analysis...”, (1997), www.shroud.com/vanhels3.htm

30. B. J Walsh, “The 1988 Shroud of Turin Radiocarbon Tests Reconsidered”, 1999 Richmond Conf. on the Turin Shroud,

http://web.archive.org/web/20040422010105/http://members.aol.com/turin99/radiocarbon-a.htm

31. M. \& A.Whanger, "The Shroud of Turin, An Adventure of Discovery," Providence House Publishers, Franklin, TN (1998), p.33.

32. G. Fanti, R. Basso, "Statistical Analysis Of Dusts Taken From Different Areas Of The Turin Shroud", Int. Conf. The Shroud Of Turin: Perspectives on A Multifaceted Enigma, Ohio State University, (2008), Libreria Progetto, Padova, Italy (2009), www.ohioshroudconference.com/papers/p16.pdf

33. M. Frei, "Il passato della Sindone alla luce della palinologia", in: "La Sindone e la Scienza", II Congr. Int. di Sindonologia, Torino, Ed. Paoline, Torino Italy (1979), pp. 191-200.

34. M. Frei "Identificazione e classificazione dei nuovi pollini della Sindone", in: "La Sindone, Scienza e Fede", II Convegno Naz. di Sindonologia, CLUEB, Bologna, Italy (1983), pp. 277-284. 
35. A. Danin , A.D. Whanger, U. Baruch, M. Whanger, "Flora of the Shroud of Turin", Missouri Botanical Garden Press, USA (1999), pp. 1-52.

36. G. Ciccone, "La truffa dei pollini. Il dossier completo", http://sindone.weebly.com/pollinil.html (2011).

37. J. A. Kohlbeck, E.L. Nitowski, "New evidence may explain image on Shroud of Turin", Biblical Archaeology Review, vol. 12, n. 4 (1986), pp.23-24.

38. P.L. Baima Bollone, "La presenza della mirra, dell'aloe e del sangue sulla Sindone", II Convegno Naz. di Sindonologia, CLUEB, Bologna. Italy (1983), pp. 169-174.

39. S. Scannerini, "Mirra, aloe, pollini e altre tracce, ricerca botanica sulla Sindone", Elle Di Ci Torino, Italy (1997).

40. Faccini B., Carreira E., Fanti G., De Palacios J., Villalain J., "The Death Of The Shroud Man: An Improved Review", Proc. Int. Conf.: The Shroud Of Turin: Perspectives on A Multifaceted Enigma, Ohio USA (2008), Libreria Progetto, Padova, Italy (2009), www.ohioshroudconference.com/papers/p07.pdf

41. P. Barbet, "The Passion of our Lord Jesus Christ", Clonmore \& Reynolds Ltd, Dublin (1954).

42. P. Barbet, "A Doctor at Calvary - The Passion of Our Lord Jesus Christ as Described By a Surgeon"; Roman Catholic Books: Fort Collins (1993).

43. R. Bucklin, R. The Legal and Medical Aspects of the Trial and Death of Christ. Science and the Law, 10, 14-26, (1970).

44. F. T. Zugibe, "The Crucifixion of Jesus: A Forensic Inquiry", 1st ed.; M. Evans and Company: New York (2005).

45. G. Fanti, C. Privitera, “A Quantitative Image of the Turin Shroud for Details Recognition”, Proc. Int. Workshop on the Scientific Approach to the Acheiropoietos Images, ENEA Research Center of Frascati, Italy (2010).

46. G. Bedon, M. Linguanotto, L. Simonato, F. Zara, "Study of the bloodstains in the Shroud of Turin. International Congress “, Int. Conf. The Shroud Of Turin: Perspectives on A Multifaceted Enigma, Ohio State University, (2008), Libreria Progetto, Padova, Italy (2009).

47. G. Fanti, P. Baraldi, , R. Basso, A. Tinti, Non-destructive dating of ancient flax textiles by means of vibrational spectroscopy, Vibrational Spectroscopy, Volume 67, P. 61-70 (2013).

48. G. Fanti, P. Malfi, "Multi-parametric micro-mechanical dating of single fibers coming from ancient flax textiles", Textile Research Journal (2013), SAGE Pub., Volume 84 Issue.

49. G. Fanti, P. Malfi, "A New Cyclic-Loads Machine For The Measurement Of Micro-Mechanical Properties Of Single Flax Fibers Coming From The Turin Shroud", AIMETA Congress, Turin, Italy (2013) http://shroudofturin.files.wordpress.com/2013/09/aimeta-fanti.pdf

50. G. Fanti, I. Calliari, C. Canovaro "Analysis of micro-particles vacuumed from the Turin Shroud", "Communication at I Int. Congr. on the Holy Shroud in Spain", Valencia, Spain (2012).

51. G. Barcaccia, G. Galla, A. Achilli, A. Olivieri, A. Torroni, "Uncovering the sources of DNA found on the Turin Shroud", accepted to Nature.

52. M. Bevilacqua, G. Fanti, M. D'Arienzo, R. De Caro, "Do we really need new medical information about the Turin Shroud?" Injury, (2013), http://dx.doi.org/10.1016/j.injury.2013.09.013 (accessed August 2015).

53. M. Bevilacqua, G. Fanti, M. D’Arienzo, A. Porzionato, V. Macchi, R. De Caro, "How was the Turin Shroud Man crucified?", Injury Vol. 45 Supp. 6 P. S142-S148 (2014), http://dx.doi.org/10.1016/j.injury.2014.10.039. 